\title{
COMPARISON OF INDIRECT COST MULTIPLIERS FOR VEHICLE MANUFACTURING
}

\author{
Technical Memorandum \\ in support of \\ Electric and Hybrid Electric Vehicle Cost Estimation Studies \\ by \\ Anant Vyas, Dan Santini, and Roy Cuenca \\ Center for Transportation Research \\ Energy Systems Division \\ Argonne National Laboratory \\ 9700 South Cass Avenue \\ Argonne, Illinois 60439
}

April 2000

Work Sponsored by United States Department of Energy Assistant Secretary for Energy Efficiency and Renewable Energy Office of Transportation Technologies 


\section{Disclaimer}

This report was prepared as an account of work sponsored by an agency of the United States Government. Neither the United States Government nor any agency thereof, nor The University of Chicago, nor any of their employees or officers, makes any warranty, express or implied, or assumes any legal liability or responsibility for the accuracy, completeness, or usefulness of any information, apparatus, product, or process disclosed, or represents that its use would not infringe privately owned rights. Reference herein to any specific commercial product, process, or service by trade name, trademark, manufacturer, or otherwise does not necessarily constitute or imply its endorsement, recommendation, or favoring by the United States Government or any agency thereof. The views and opinions of document authors expressed herein do not necessarily state or reflect those of the United States Government or any agency thereof, Argonne National Laboratory, or The University of Chicago. 


\section{COMPARISON OF INDIRECT COST MULTIPLIERS FOR VEHICLE MANUFACTURING}

\section{INTRODUCTION}

In the process of manufacturing and selling vehicles, a manufacturer incurs certain costs. Among these costs are those incurred directly as a part of manufacturing operations and those incurred indirectly in the processes of manufacturing and selling. The indirect costs may be productionrelated, such as R\&D and engineering; business-related, such as corporate staff salaries and pensions; or retail-sales-related, such as dealer support and marketing. These indirect costs are recovered by allocating them to each vehicle. Under a stable, high-volume production process, the allocation of these indirect costs can be approximated as multipliers (or factors) applied to the direct cost of manufacturing. A manufacturer usually allocates indirect costs to finished vehicles according to a corporation-specific pricing strategy. Because the volumes of sales and production vary widely by model within a corporation, the internal corporate percent allocation of various accounting categories (such as profit or corporate overhead) can vary widely among individual models. Approaches also vary across corporations. For our purposes, an average value is constructed, by means of a generic representative method, for vehicle models produced at high volume. To accomplish this, staff at Argonne National Laboratory's (ANL's) Center for Transportation Research analyzed the conventional vehicle cost structure and developed indirect cost multipliers for passenger vehicles.

This memorandum summarizes the results of an effort to compare and put on a common basis the cost multipliers used in ANL's electric and hybrid electric vehicle cost estimation procedures with those resulting from two other methodologies. One of the two compared methodologies is derived from a 1996 presentation by Dr. Chris Borroni-Bird of Chrysler Corporation, the other is by Energy and Environmental Analysis, Inc. (EEA), as described in a 1995 report by the Office of Technology Assessment (OTA), Congress of the United States. The cost multipliers are used for scaling the component costs to retail prices.

\section{ANL METHODOLOGY}

The ANL methodology described here is based on an analysis concerned with electric vehicle production and operating costs (Cuenca et al. 2000; Vyas et al. 1998). The analysis evaluated the cost structure for conventional vehicle manufacturing and retailing and assigned shares of the manufacturer's suggested retail price (MSRP) to various cost contributors. Multipliers developed from the ANL methodology are applied to the manufacturing cost of an individual component in order to scale the component cost to the retail price. Several cost contributors are included in the methodology, as summarized in Table 1.

Some of the vehicle components for electric and hybrid electric vehicles would be procured from outside suppliers. This assumption is applied to electric drive components, excluding the battery; the vehicle manufacturer would produce the rest. Thus, two cost multipliers, one for the components manufactured internally and the other for outsourced components, are necessary to estimate the price of electric and hybrid electric vehicles. Outside suppliers would incur some of the costs normally borne by the vehicle manufacturer. In the ANL methodology, we assume that the costs of "Warranty," "R\&D/Engineering," and "Depreciation and Amortization" are borne by the 
suppliers of outsourced components. The outside suppliers would include these costs in their prices. The following two cost multipliers are computed by using "Cost of Manufacture" as the base:

Cost multiplier for components manufactured internally $=100 / 50=2.00$.

Cost multiplier for outsourced components $=100 /(50+6.5+5.5+5)=1.50$.

Table 1 Contributors to Manufacturer's Suggested Retail Price in ANL Methodology

\begin{tabular}{|l|l|c|c|}
\hline \multicolumn{1}{|c|}{ Cost Category } & \multicolumn{1}{|c|}{ Cost Contributor } & $\begin{array}{c}\text { Relative to } \\
\text { Cost of Vehicle } \\
\text { Manufacturing }\end{array}$ & $\begin{array}{c}\text { Share of } \\
\text { MSRP } \\
(\%)\end{array}$ \\
\hline Vehicle Manufacturing & Cost of Manufacture & 1.00 & 50.0 \\
\hline Production Overhead & Warranty & 0.10 & 5.0 \\
& R\&D/Engineering & 0.13 & 6.5 \\
& Depreciation and Amortization & 0.11 & 5.5 \\
\hline Corporate Overhead & Corporate Overhead, Retirement and & 0.14 & 7.0 \\
& Health & & \\
\hline Selling & Distribution, Marketing, Dealer & 0.47 & 23.5 \\
\hline Sum of Costs & Support, and Dealer Discount & 1.95 & 97.5 \\
\hline Profit & Profit & 0.05 & 2.5 \\
\hline Total Contribution & & 2.00 & 100.0 \\
MSRP & & & \\
\hline
\end{tabular}

\section{METHODOLOGY DERIVED FROM BORRONI-BIRD PRESENTATION}

In his presentation, entitled "Automotive Fuel Cell Requirements," at the 1996 Automotive Technology Development Customers' Coordination Meeting, Borroni-Bird included charts on the "Typical American Automobile: Price/Cost Breakdown." The charts provided a graphical breakdown of vehicle price, showing cost contributors and profit. We used the charts to arrive at percentage shares of vehicle price by various contributors. Table 2 shows the resulting allocation. 
Table 2 Price/Cost Breakdown Based on Borroni-Bird Presentation

\begin{tabular}{|c|c|c|c|}
\hline Cost Category & Cost Contributor & $\begin{array}{c}\text { Relative to Cost of } \\
\text { Vehicle } \\
\text { Manufacturing } \\
\end{array}$ & $\begin{array}{c}\text { Share of } \\
\text { MSRP } \\
(\%)\end{array}$ \\
\hline $\begin{array}{l}\text { Vehicle } \\
\text { Manufacturing }\end{array}$ & $\begin{array}{l}\text { Material Cost }{ }^{\mathrm{a}} \\
\text { Assembly Labor and Other Manufacturing } \\
\text { Costs }^{\text {a }}\end{array}$ & $\begin{array}{l}0.87 \\
0.13\end{array}$ & $\begin{array}{r}42.5 \\
6.5\end{array}$ \\
\hline Fixed Cost & $\begin{array}{l}\text { Transportation/Warranty } \\
\text { Amortization and Depreciation, Engineering } \\
\text { R\&D, Pension and Health Care, } \\
\text { Advertising, and Overhead }\end{array}$ & $\begin{array}{l}0.09 \\
0.44\end{array}$ & $\begin{array}{r}4.5 \\
21.5\end{array}$ \\
\hline Selling & $\begin{array}{l}\text { Price Discounts } \\
\text { Dealer Markup }\end{array}$ & $\begin{array}{l}0.10 \\
0.36\end{array}$ & $\begin{array}{r}5.0 \\
17.5 \\
\end{array}$ \\
\hline Sum of Costs & & 1.99 & 97.5 \\
\hline Profit & Automobile Profit & 0.06 & 2.5 \\
\hline MSRP & & 2.05 & 100.0 \\
\hline
\end{tabular}

a These two contributors are scaled to sum to 1 in the third column, as in Table 1.

In his presentation, Borroni-Bird did not evaluate the treatment of in-house or outsourced components. His methodology does not lend itself to easy computation of cost multipliers comparable with those in the ANL methodology, unless we make a few assumptions. We have assumed that "Material Cost," taken together with "Assembly Labor and Other Manufacturing Costs," would form the "Vehicle Manufacturing" base for the in-house components. The costs of "Transportation/Warranty," "Amortization and Depreciation," and "Engineering R\&D" would be borne by the suppliers of outsourced components. However, "Amortization and Depreciation" and "Engineering R\&D" costs were merged with "Pension and Health Care," "Advertising," and "Overhead" costs by Borroni-Bird. We assumed that half of the costs under this category would be borne by the suppliers of outsourced components. Our assumptions led to the following cost multipliers:

Cost multiplier for components manufactured internally $=100 /(42.5+6.5)=2.05$.

Cost multiplier for outsourced components $=100 /(42.5+6.5+4.5+10.75)=1.56$.

These cost multipliers are very similar to those computed with the ANL methodology.

\section{Comparison of ANL and Borroni-Bird Methodologies}

The information from Tables 1 and 2 is shown in terms of cost categories in Table 3. Both methodologies use vehicle manufacturing cost as the base and add other costs to it. The share of MSRP attributable to "Vehicle Manufacturing" is 50\% in the ANL methodology, compared with $49 \%$ in the Borroni-Bird Methodology. Borroni-Bird combined several cost contributors under "Fixed Cost." These contributors include (see Table 2) "Amortization and Depreciation," "Engineering R\&D," "Pension and Health Care," "Advertising," and "Overhead." Except for the inclusion of "Advertising," "Production Overhead" and "Corporate Overhead" in the ANL methodology can be combined to form an equivalent category. ANL's total of $24 \%$ by production 
and corporate overheads is slightly lower than the total of $26 \%$ by Borroni-Bird. The ANL category of "Selling," which includes "Distribution," "Marketing," "Dealer Support," and "Dealer Discount," is broader than that of "Price Discounts" and "Dealer Markup" specified by BorroniBird, and this category's contribution is understandably slightly higher in the ANL methodology. The share of MSRP by "Profit" is the same in both methodologies. The absolute differences, computed as ANL value minus Borroni-Bird value, are 1\% for "Vehicle Manufacturing," $-2 \%$ for "Fixed Cost," and $1 \%$ for "Selling" cost.

Table 3 Comparison of Vehicle Price/Cost Allocation by ANL and Borroni-Bird Methodologies

\begin{tabular}{|l|c|l|c|}
\hline \multicolumn{2}{|c|}{ ANL Methodology } & \multicolumn{2}{c|}{ Borroni-Bird Methodology } \\
\hline Cost Contributor or Category & $\begin{array}{c}\text { Share of } \\
\text { MSRP (\%) }\end{array}$ & Cost Contributor or Category & $\begin{array}{c}\text { Share of } \\
\text { MSRP (\%) }\end{array}$ \\
\hline Vehicle Manufacturing & 50.0 & Vehicle Manufacturing & 49.0 \\
\hline Production Overhead & 17.0 & Fixed Cost & 26.0 \\
\hline Corporate Overhead & 7.0 & & 22.5 \\
\hline Selling & 23.5 & Selling & 97.5 \\
\hline Sum of Costs & 97.5 & Sum of Costs & 2.5 \\
\hline Profit & 2.5 & Automobile Profit & 100.0 \\
\hline MSRP & 100.0 & MSRP & \\
\hline
\end{tabular}

\section{EEA METHODOLOGY}

The methodology of Energy and Environmental Analysis is summarized in the OTA report OTAETI-638, entitled Advanced Automotive Technology: Visions of a Super-Efficient Family Car, published in September 1995. The values of some cost contributors are not listed in the report. Moreover, depreciation, amortization, and tooling expenses are assumed to be case-specific and therefore must be computed for each case. In order to make the EEA and ANL methodologies comparable, some assumptions were necessary. These assumptions are described in the summary below.

The EEA cost equations can be simplified as follows:

Cost of Manufacture $=$ Division Cost $\times[1+$ Division Overhead $]$

Manufacturer Cost $=[$ Cost of Manufacture + Assembly Labor + Assembly Overhead $] \times$ [1 + Manufacturing Overhead + Manufacturing Profit $]+$ Engineering Expense + Tooling Expense + Facilities Expense

Retail Price Equivalent $=$ Manufacturer Cost $\times[1+$ Dealer Margin $]$ 
The report lists the following values for overhead, profit, and dealer margin:

Division Overhead $=$ Supplier Overhead $=0.20$

Manufacturing Overhead $=0.25$

Manufacturing Profit $=0.20$

Dealer Margin $=0.25$
(We assume that division and supplier overheads are equal; only the supplier overhead is given in the report.)

Because the documentation in the OTA report does not provide values for "Assembly Labor," "Assembly Overhead," "Engineering Expense," "Tooling Expense," and "Facilities Expense," cost multipliers cannot be computed directly from these data. The "Assembly Labor" and "Assembly Overhead" share of MSRP is 6.5\% in Borroni-Bird's presentation. The engineering, tooling, and facilities expenses can be taken as the sum of "R\&D/Engineering" and "Depreciation and Amortization" from the ANL methodology, at $12 \%$ of the MSRP. In deriving the division cost and price relationship below, we use the term Retail Price Equivalent (RPE) from the OTA report instead of MSRP. The RPE can be computed as follows:

$\begin{array}{rll}\mathrm{RPE} & = & \{[\text { Division Cost } \times 1.2+0.065 \mathrm{RPE}] \times 1.45+0.12 \mathrm{RPE}\} \times 1.25 \\ & =\quad \text { Division Cost } \times 2.175+0.268 \mathrm{RPE} \\ & =\quad \text { Division Cost } \times 2.175 /(1-0.268)=\text { Division Cost } \times 2.97\end{array}$

\section{Putting ANL and EEA Methodologies on a Common Basis}

As it was described in the OTA report, the EEA methodology did not provide enough data to compute the cost multipliers. We assumed some cost shares to be the same between the EEA, Borroni-Bird, and ANL methodologies while developing the above relationship between Division Cost and RPE. The EEA methodology is based on the material and labor costs of a division of the vehicle manufacturer, with other costs added on. The ANL methodology evaluates an assembled vehicle, using the vehicle manufacturing cost as the base cost. The ANL methodology also assigns additional costs to the outsourced components, whereas the treatment of such components is not clear in the EEA methodology. We have attempted to develop a common basis for the ANL and EEA methodologies by assigning shares of the final vehicle price, RPE in the EEA methodology, to individual cost categories similar to those listed in Table 1. Table 4 presents such a summary for the EEA methodology.

Three cost contributors, "Division Cost," "Division Overhead," and "Assembly Labor and Overhead," are combined under the "Vehicle Manufacturing" category. Two cost contributors, "Manufacturing Overhead" and "Engineering, Tooling, and Facilities Expenses," combine to form the "Overhead" category. The "Dealer Margin" in the EEA methodology represents a factor applied to all manufacturer costs and profit. We assumed that this factor represents all costs of selling the vehicle. Although the profit is computed at the manufacturing level by EEA, we moved the profit to the bottom of the table to be consistent with prior tables. The cost allocation in Table 4 allows us to compute the in-house components cost multiplier as follows:

Cost multiplier for in-house components $=100 /(33.7+6.7+6.5)=2.14$ 
To compute the cost multiplier for an outsourced component, one more assumption is necessary. In the ANL methodology, we assumed that the supplier will bear the costs of "Warranty," "R\&D Engineering," and "Depreciation and Amortization." However, the EEA methodology does not identify the warranty cost separately. We assumed it to be half of "Manufacturing Overhead" at $5.05 \%$. This, with the earlier assumption related to "Engineering, Tooling, and Facilities Expenses," led to the following computation:

$$
\text { Cost multiplier for outsourced components }=100 /(33.7+6.7+6.5+5.05+12)=1.56
$$

These multipliers, adapted from our extension of the EEA information on vehicle costs, are very close to those derived from the ANL and Borroni-Bird methodologies.

Table 4 Contributors to Retail Price Equivalent in EEA Methodology

\begin{tabular}{|c|c|c|c|}
\hline Cost Category & Cost Contributor & $\begin{array}{c}\text { Relative to Cost of Vehicle } \\
\text { Manufacturing }\end{array}$ & $\begin{array}{l}\text { Share of } \\
\text { RPE }(\%)\end{array}$ \\
\hline $\begin{array}{l}\text { Vehicle } \\
\text { Manufacturing }\end{array}$ & $\begin{array}{l}\text { Division Cost }^{\mathrm{a}} \\
\text { Division Overhead }^{\text {a }} \\
\text { Assembly Labor and } \\
\text { Overhead }\end{array}$ & $\begin{array}{l}0.72 \\
0.14 \\
0.14\end{array}$ & $\begin{array}{r}33.7 \\
6.7 \\
6.5\end{array}$ \\
\hline Overhead & $\begin{array}{l}\text { Manufacturing Overhead } \\
\text { Engineering, Tooling, and } \\
\text { Facilities Expenses }\end{array}$ & $\begin{array}{l}0.22 \\
0.26\end{array}$ & $\begin{array}{l}10.1 \\
12.0\end{array}$ \\
\hline Selling & Dealer Margin & 0.49 & 22.9 \\
\hline Sum of Costs & & 1.97 & 91.9 \\
\hline Profit & Manufacturing Profit & 0.17 & 8.1 \\
\hline $\begin{array}{l}\text { Total Contribution } \\
\text { to RPE }\end{array}$ & & 2.14 & 100.0 \\
\hline
\end{tabular}

${ }^{\mathrm{a}}$ These three cost contributors are scaled to sum to 1 in the third column, as in Table 1.

\section{Comparison of ANL and EEA Methodologies}

The information from Tables 1 and 4 is presented in terms of cost categories in Table 5 for easy comparison. The "Vehicle Manufacturing" cost share is $46.9 \%$ in the EEA methodology, compared with $50 \%$ in the ANL methodology. EEA's RPE share of $22.1 \%$ by overhead is lower than the ANL value of $24 \%$. The cost of selling is $22.9 \%$ in the EEA methodology, which is close to the ANL value of $23.5 \%$. The largest difference is in the RPE share by profit, which is $8.1 \%$ in the EEA methodology, more than three times the ANL value of 2.5\%. According to Economic Indicators: The Motor Vehicle's Role in the U.S. Economy (American Automobile Manufacturers Association 1998), the average net income before taxes for the three domestic manufacturers was 3.9\% during 1994-1997. Aside from vehicle sales, this value (3.9\%) includes income from spare parts sales and vehicle financing. Thus, the profit share appears very high in the EEA methodology. The absolute differences - computed as ANL value minus EEA value - are $3.1 \%$ for component/material cost, $1.9 \%$ for overhead, $0.6 \%$ for selling, and $-5.6 \%$ for profit. 
Table 5 Comparison of Price Allocation by ANL and EEA Methodologies

\begin{tabular}{|l|c|l|c|}
\hline \multicolumn{2}{|c|}{ ANL Methodology } & \multicolumn{2}{c|}{ EEA Methodology } \\
\hline Cost Contributor or Category & $\begin{array}{c}\text { Share of } \\
\text { MSRP (\%) }\end{array}$ & Cost Contributor or Category & $\begin{array}{c}\text { Share of } \\
\text { RPE (\%) }\end{array}$ \\
\hline Vehicle Manufacturing & 50.0 & Vehicle Manufacturing & 46.9 \\
\hline Production Overhead & 17.0 & Overhead & 22.1 \\
\hline Corporate Overhead & 7.0 & & \\
\hline Selling & 23.5 & Selling & 22.9 \\
\hline Sum of Costs & 97.5 & Sum of Costs & 91.9 \\
\hline Profit & 2.5 & Profit & 8.1 \\
\hline MSRP & 100.0 & RPE & 100.0 \\
\hline
\end{tabular}

\section{SUMMARY}

An attempt to put three methodologies for automobile cost allocation on a common basis is presented in this technical memorandum. This comparison was carried out to verify the reasonableness of the cost multipliers used in ANL's cost models for electric vehicles and hybrid electric vehicles. When put into a common format, by means of certain assumptions, the three approaches yielded the cost multipliers provided in Table 6.

Table 6 Summary of Cost Multipliers Computed on a Common Basis

\begin{tabular}{|l|c|c|c|}
\hline \multicolumn{1}{|c|}{ Multiplier for } & ANL & Borroni-Bird & EEA \\
\hline In-House Components & 2.00 & 2.05 & 2.14 \\
\hline Outsourced Components & 1.50 & 1.56 & 1.56 \\
\hline
\end{tabular}

\section{ACKNOWLEDGMENT}

Funding for the analysis presented here was provided by the Planning and Assessment function of the Office of Transportation Technologies of the U.S. Department of Energy, managed by Dr. Philip Patterson. This technical memorandum is produced under U.S. Government contract No. W-31-109-Eng-38.

\section{REFERENCES}

American Automobile Manufacturers Association, 1998, Economic Indicators: The Motor Vehicle's Role in the U.S. Economy, Detroit, Mich.

Borroni-Bird, C., 1996, "Automotive Fuel Cell Requirements," Proceedings of the 1996 Automotive Technology Development Customers' Coordination Meeting, U.S. Department of Energy, Office of Transportation Technologies, Washington, D.C. 
Cuenca, R.M., L. L. Gaines, and A. D. Vyas, 2000, Evaluation of Electric Vehicle Production and Operating Costs, Argonne National Laboratory Report ANL/ESD-41, Argonne, Ill. (to be published).

Vyas, A., R. Cuenca, and L. Gaines, 1998, "An Assessment of Electric Vehicle Life Cycle Costs to Consumers," Proceedings of the 1998 Total Life Cycle Conference, SAE International Report P339, Warrendale, Penn., pp. 161-172. 